\title{
Student life observatory: considerations on the profile of young people at a federal university of the Mercosur frontier Mesoregiao-Brazil
}

\begin{abstract}
The study aimed to analyze the professional career of the graduates of the first class of directors of UFFS, Campus Chapecó. For this, we used a methodology nature of quantitative and qualitative and questionnaires with open and closed questions with the graduates, one year after the completion of graduation. In the data analysis, it was found that the graduation diploma did not provide improvements in current conditions, because there is no equivalence between the busy job and the level of education. The study shows dissonance between the current educational training in the country and the demands of the labor market, given the planned obsolescence of professional knowledge required. Amid this, the graduates perform individual strategies to seek a spread of other, extending their education, are attending a post side meaning or strictly speaking, also as an alternative to unemployment.
\end{abstract}

Keywords: university, graduate, graduates, university, degree, professional, educational, institution
Volume 3 Issue I - 2019

\author{
Valeria De Bettio Mattos \\ Department of Sociology, Federal University of Santa Catarina, \\ Brazil \\ Correspondence: Valeria De Bettio Mattos, Department of \\ Sociology, Lecturer at the Federal University of Santa Catarina, \\ Florianopolis Area, Brazil, Email valeria.mattos@ufsc.br
}

Received: November 08, 2018 | Published: February 12, 2019

\section{Introduction}

Training in higher education appears to be increasingly important for young people wishing to qualify professionally, as well as those who crave a more citizen life, along with the entry and stay in the labor market. UFFS It is a public and popular higher education institution, concern to provide opportunities for young people from public schools, through access to free education and quality. The institution was established by Law No. 12029 of September 15, 2009, its activities began in March 2010, with coverage to 396 municipalities in the Greater Region Border MERCOSUR - Paraná Southwest, west of Santa Catarina and Rio Grande do Sul Northwest. It is present in Chapecó-headquarters of the institution, Royalty and South Orange and Cerro Largo, Erechim and Passo Fundo (RS).

When considering that the UFFS is the result of REUNI, one of its pillars is to restructure the Brazilian higher education, in order to move the federal universities in the regions historically neglected by the government, both to provide free higher education, as the search for better teaching quality. This paper aims to examine the professional trajectory of graduates of the first class of directors of UFFS, Campus Chapecó, seeking dwrite the student profile degree in Business Administration in UFFS, evaluate the micro-social context in which the Board of egress is inserted, as well as discuss the insertion of graduates in the labor market.

\section{Study problem}

In surveys conducted by Pochman ${ }^{1} \&$ Sarriera et al., ${ }^{2}$ young people from economically disadvantaged classes see the professional development opportunities limited with so many qualification requirements and demands. As Sarriera, ${ }^{2}$ these young people present, mostly low schooling, a factor that can put them in the group of unemployed or underemployed. When challenged to reflect on possibilities for change, expressed interest in improving their conditions from increased schooling and qualifications, placing themselves as solely responsible for their condition, without realizing the complexity in which they are involved.
In a survey conducted on the educational reality and the young Brazilian insertion economically disadvantaged in the labor market, Lisbon and Welter ${ }^{4}$ note that the early entry of young workers in the condition contributes to a high dropout rate. According to this study, young people with family income per capita above $40 \%$ of the minimum wage, $74.2 \%$ are enrolled in higher education and working simultaneously. This reality points out that the low-income student is outdated in terms of schooling, either by entering the market early, either by truancy. Romanelli, ${ }^{5}$ Resende et al., ${ }^{6}$ Foracchi $^{7}$ \& Guimarães $^{8}$ find that the paths are different according to social origin, especially in a difficult environment, where the trajectories are built unsafely requiring regular adjustments in the field of work and education. The emblematic figure of this is the condition of the worker-student studying possibly according to your non-working time and economic resources it has.

However, Poullaouec ${ }^{9}$ notes that the diploma is still the 'weapon' of the weak, since this type of certification serves as a decisive tool in the professional integration of people from popular media. Beaud ${ }^{11}$ states that a collective phenomenon is experienced individually responsible individuals about their destinations. Thus, he argues: The standardized school privatization biographies, making each responsible for their fate: professional success depends on today's school success, which seems to be related exclusively to the individual qualities of the person concerned (p. 16). Such understandings require deepening through empirical research that focuses on the question of the permanence of young people in higher education, the immediate plan and, concomitantly or in the medium term in the world of work.

\section{Methodology}

To meet the objectives of this research is proposed in a study of quantitative and qualitative. ${ }^{11,12}$ The mixed approach allows the elaboration of questions and looking for answers to understand the strategies and the professional and personal trajectory of young graduates of the course of Directors of UFFS. Thus, the instrument was a questionnaire sent via Google Docs in the first half of 2015 related to the trainees of 2014.1. For analysis, we used either a 
comparison of the information, either an individual analysis of the responses. Thus, the data answer the central question of the study come from opinions, but are transformed into quantifiable elements to this, we used predominantly scales of Likert. Still, the questionnaire closed questions were applied in the respondent "just mark with an $\mathrm{X}$ the answer that is most significant"13 and also open questions, so that you can capture the free expression of the interviewee. ${ }^{13}$ This ensures the accuracy in terms of results, characterized as qualitative and quantitative studies. Regarding the sample formed $75 \%$ of respondents, which corresponds to nine (9) graduates from a group composed of twelve (12), thus representing the first group of Administration formed in 2014.1 in UFFS.

\section{Results}

When considering the study of Miano \&Vieira ${ }^{14}$ about the career prospects of graduates in Business Administration, the purpose of forming professionally for future employment and the will to get improvement in employment status is because there is an induction by decreasing power contract, that is, there is a need to adapt constantly to the levels imposed by the labor market in order not to be excluded. Thus, the individual is responsible for job search and qualification, given that it is required it greater autonomy and control in participating in the market, in order to develop the so-called employability. Today, career, is no longer considered a "linear sequence of experiences or positions structured in time and space"14 but, subsequent stages, according to the adjustments to the demands the world of work, in terms of knowledge, skills. Therefore, it is necessary to plan personal goals and strategies both for the insertion, and for the maintenance in the labor market.

The changing scenario of insertion and maintenance in the working world impinge education assigning enhance the employability of young graduates. Therefore, the quest for continuing education becomes competitive strategy. ${ }^{14,15}$ The speech of egress and expresses the internalized ideology: "I am seeking to acquire knowledge and experience and demonstrate the ability I hold." According to Mattos, ${ }^{16}$ the young man seeks to improve the conditions, through the lengthening of their schooling themselves responsible for their qualifications in order to ensure their employability. In assessing the employment situation in which graduates were immediately after completing graduation in 2014.1, it was found that $56 \%$ remained unemployed for a period of up to five months and $44 \%$ were working.

The justification for the inactivity can be given by the need for career planning, how you justify the egress C: "In this period pay proof of masters and dedicated my time in setting up a company with three other partners, so was unemployed." Or it is because of indecision, for example, the egress that I remained unemployed "to decide what I really wanted to do." In others were "looking for a better opportunity," as justification for egress E. The context Chapecó-SC, a city where the research was developed special features which explain the observed reality. According to Sebrae, ${ }^{17} 93 \%$ of companies in the region are micro-familiar and singular and only $0.3 \%$ are large companies that cover $39 \%$ of the jobs in the region, mostly in operational levels, with low compensation and requiring low level of education.

That is, even if the egress seeks qualification to bargain a better situation, it is natural to face integration difficulties in the region, despite the west of Santa Catarina is known as a hub of agribusiness. In general, force in the region two alternatives: working in large companies in operational levels that require few qualifications, or fit the family business, as expressed egress B: "I think I was looking for something my city not could offer." To Fiod ${ }^{18}$ is a mistake to attribute to education the solution of historical problems, because they stem from pre-established social relations in specific contexts. Gentili ${ }^{19}$ notes that Latin Americans are the most educated and also the poorest today. The author justifies "in a powdered, segmented school system in which they live educational circuits various opportunities and qualities", the opportunities appear according to the social condition of the subject and the resources you have to access them.

The temporized scenario provides a number of "empty certifications" Because in many cases, the university performs the exclusion of the worker-student. ${ }^{5}$ According Kuenzer, ${ }^{20}$ there is an exclusion-inclusive as identify "several strategies to exclude the employee from the formal market, where he had secured rights and better working conditions and at the same time, are placed strategies inclusion in the labor market, under precarious conditions." The author notes that occurs simultaneously adding-exclusive when "inclusion strategies of the various levels and types of education which do not meet the quality standards that allow the formation of intellectual autonomous identities and ethically". ${ }^{20}$ Ie the newly formed youth does not meet the standard demands of current capitalist accumulation, the so-called productive restructuring, ${ }^{21}$ it has not acquired enough experience to work in accordance with the precepts of versatility, flexibility and ability to anticipate and solve problems quickly and efficiency demanded by the market. ${ }^{20}$

If you expect a manager-worker is competent to argue the point, work in teams and under pressure, who knows how to negotiate, "lead, receive feedback, and address frustrations and uncertainties undoubtedly be resilient and stay healthy to be a constant promoter of quality and continuous improvement". ${ }^{22}$ Since the employer the goal is to "invest in vocational training in order to increase productivity". 16 This scenario tends to increase quality and business competitiveness since Canals \&Sandrine ${ }^{23}$ find that most skilled workers produce about $30 \%$ more, when compared to unskilled. Already the employee such inducement to continue their studies ensures their survival. ${ }^{22}$ When analyzing the performance of graduates in the labor market prior to obtaining the degree title, $56 \%$ had no experience in the training area and today one year-this figure dropped to $22 \%$, who continue to work on activities that have no relation directly with management. In addition to the data that currently $56 \%$ of them work indirectly with the area, as seen in Figure 1. By way of illustration, this second percentage, the egress I said: My goal as a professional was overcome, thought to work in a company and ended up opening my! However, still I cannot reach my goals as "businesswoman", starting a business requires time and patience. While colleagues should be earning a salary compatible with their training, I take management fees based on a minimum wage (Figure 1).

Ie even earn a minimum wage and find themselves in precarious working conditions, the egress feel satisfied with the situation, believing be investing in planning your career. The egress $\mathrm{C}$, which makes up a share of $22 \%$, argued that "I can say that I have still much to grow" and said: "My goal for this stage of professional career was to be attending the Masters. I got it and even opened a company in society, something I longed for in a couple of 10 years, at least." Given this context, the "social mobility dream remains only as a process for most titled" ${ }^{16}$ because, although the graduates C and I have opened your business, are still in instability in the labor market, however, aspire and plan to succeed in the future. By analyzing the insertion in the market, you can see that most opted for the paid employment 
strategy, ${ }^{1}$ two of which have opted for autonomous action and doing other exchanges abroad, as (Table 1).

Table I Current occupation of graduates 20I4.I and time of work.

\begin{tabular}{lll}
\hline Grads & Current occupation & Operating time \\
\hline THE & Admnistrative technician & Recently \\
B & exchange student & Seven months \\
W & Strategic Management (Administrator) & Recently \\
D & Financial aid & Seven months \\
AND & Fleet Auxiliary & Eight months \\
F & Administrative assistant & Seven months \\
G & Administrative Assistant & Seven months \\
H & Office assistant & Nine months \\
I & Strategic Management (Administrator) & Recently \\
\hline
\end{tabular}

Source: Prepared by the Authors (20I5).

Gráfico 2 - Experiência profissional das egressas 2014.1

" Antes Apósformado

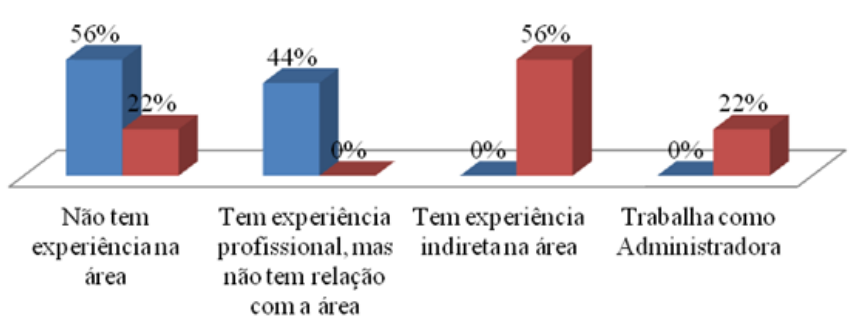

Figure I Professional experience of the alumni 2014.

Source: Prepared by the Authors (2015).

In this context, Prandi ${ }^{24}$ reports that the university is considered a way to slow the inflow of young people into the labor market. It is worth remembering that this educational institution does not have the responsibility to allocate professionals, but forming them roughly in a general way. The concept about the general education and professional unstable performance can be compared to the current situation of the investigated graduates, in which only one has full satisfaction through their current achievements: I won my goals, I could exchange it was my first choice, after graduation, and came in third. During after training, first got a job that provided me take for 4 months and work directly with the public organizing events, but over time was no longer financially satisfactory, so I went looking for work in a large company. In analyzing the situation of continuing studies, it was found that three of them are not studying at the time. It thus appears that the inflation of the diploma makes rather demand decrease tends to increase and also the demand for subsequent courses (lato sensu or strict sense), whose prerequisite is the completion of undergraduate. ${ }^{16}$ Young people feel responsible for the success or failure of integration in jobs commensurate with their training and characterize the lengthening of education as a strategy for better working conditions, no guarantee insertion in the labor market. Thus, graduates perform strategies to differentiate themselves, like, attend two degrees together, attending broad sense postgraduate courses or strict sense to strengthen career development, through the networks that are established in the training- employment context, ${ }^{16}$ although, most of the graduates have functions that require education level below the title they hold. ${ }^{25,26}$

This can be seen in the speech of egress I, who comments: "my expectations were exceeded. My goal for this stage of professional career was to be attending the Masters. "Still, the egress A says he is motivated by the job you have, because it allows to carry out "further study, as well as the opportunity to apply for internal positions, linked to the training area." With regard to satisfaction, it is clear dissatisfaction with the situation in which they find themselves. For egress and, "I'm still in search of the desired position, I have the possibility of acting in the people management area." The egress D also said: "Not intended to still be working in the company of my family, I would have walked other career paths."

\section{Conclusion}

It was found that the graduation diploma did not provide immediate improvements in employability of graduates, because they still occupy lower positions that obtained diploma. The study shows that egresses attempts seek to differentiate, and avoid unemployment, such as further studies. However, the university education has no responsibility to allocate professionals in the labor market, since attached a universalizing education and not merely technical.

\section{Acknowledgments}

None.

\section{Conflicts of interest}

The author declares that no conflict of interest exists in publishing this article.

\section{References}

1. Pochmann M. Education and Work: How to develop a virtuous relationship? Education and Society. 2004;25(87):383-399.

2. Sarriera JC. Community Psychology: Current studies. Brasil: Porto Alegre southern fringes; 2000. 468 p.

3. Bauman Z. Liquid Modernity. Rio de Janeiro: Zahar; 2001. 192 p.

4. Lisboan MD, Welter GMR. Prospects of Education and work in Brazil. In: Democratic Politics. Brasilia. 2009.

5. Romanelli G. Families of middle class and higher education of the children: The working student. In: Walnut MA, editor. Family and school: school trajectory in middle and lower classes. Petropolis, RJ: Voices; 2003. 17 p.

6. Resende TF, Walnut C MM, Walnut MA, et al. Family profiles and types of schools: challenges and issues for sociological analysis. In: Proceedings of the 32nd Annual Meeting of the ANPED. CAXAMBU/ MG; 2009.

7. Foracchi MM. The student and the transformation of Brazilian society. São Paulo: Editora Nacional; 1965. 34 p.

8. Guimaraes NA. Unsafe Trajectories, uncertain empowerment: young people and labor markets under intense occupational transitions. São Paulo: CEO; 2007.7 p.

9. Poullaouec T. Le diplôme, l'arme des faible: Les familles Ouvrières et l'école. Paris: La Dispute; 2010. 225 p.

10. Beaud S. $80 \%$ S. et après au bac? Les enfants de la Democratization scolaire. Paris: Éditions la découverte; 2002. 288 p. 
11. Triviños ANS. Introduction to social science research: qualitative research in education. São Paulo: Atlas; 1992. 159 p.

12. Minayo, Maria Cecilia de Souza. Social research: theory, method and creativity. Petropolis: Voices, 1999. 224 p.

13. Virgillito SB. Search marketing: a quantitative approach and quality. São Paulo: Saraiva, 2010.

14. Miano VY, Vieira FO. Career prospects of Administration graduates of IFES. Magazine Contemporary Thought Administration (RPCA). Rio de Janeiro: Fluminense Federal University. 2012;6(1):72-90.

15. Frigotto G. Education and the real capitalist crisis. Third ed. São Paulo: Cortez; 1999. $581 \mathrm{p}$.

16. Mattos V. Postgraduate in precarious times of work: lengthening of schooling and alternative to unemployment. São Paulo: Shaman; 2011.

17. Sebrae. Santa Catarina in Numbers. Florianopolis SEBRAE/SC. 2010.

18. Fiod EGM. The mollusk education that turns man. In: Aued, Bernardete Wrublevski, editors. Education for (un) employment. Petrópolis, RJ: Voices; 1999. pp. 100-137.

19. Gentili P. Three theses on the relationship between work and education in neoliberal times. In: Lombardi JC, Saviani D, editors. Capitalism, work and education. Third ed. Campinas, SP: Histedbr; 2005. 12 p.
20. Kuenzer AZ. inclusive exclusion and exclusionary inclusion: a new form of structural duality that objective the new relationships between education and work. In: Lombardi JC, Saviani D, editors. Capitalism, work and education. Third ed. Campinas, SP: Histedbr; 2005. pp.77-96.

21. Alves G. The new (and precarious) world of work: productive restructuring and labor's crisis. São Paulo: Boitempo; 2000. 26 p.

22. Luna IN. Productive restructuring and the profession of managing companies: the Taylorist management to worker self-manager. Thesis (Doctorate in Political Sociology)-Post-Graduate Program in Political Sociology, Federal University of Santa Catarina, Florianópolis, 2008.

23. Canals V, Sandrine M. La formation-insertion: vers une nouvelle forme d'emploi? Sciences de la modernity. 2009;36:112-117.

24. Prandi JR. Degraded favorites. São Paulo: Loyola; 1982.

25. Brazil. Creates the Support Program for the Restructuring and Expansion of Federal Universities-MEETING. Brasilia: Presidency of Republic House: Subchefia for Legal Affairs; 2002. 44 p.

26. Uller Reginaldo. Professionalization in family business: The case of Agroindustrial S/A. Paper presented to the Course of Postgraduate Production Engineering Technological Federal University of Santa Catarina Center to obtain the Master title Production Engineering. Florianópolis; 2002. 